\title{
Homeschooling as an Alternative Option in Light of the Virus Restrictions ${ }^{1}$ Stuart Nicolson
}

\begin{abstract}
School closures during the time of virus restrictions have caused upheaval for the education of most children except for homeschoolers, who remain mostly unaffected. For parents to choose to homeschool their children, there need to be both reasons and opportunity, and already there has been an increase in parents choosing this option in some countries. This article looks briefly at the current educational context: the negative experiences of most children, parents, and teachers during the restrictions; the general advantages and disadvantages of homeschooling; and the state of homeschooling currently in the Czech Republic, which has been growing at a significant rate in recent years. A number of reasons, especially in the current time, are then considered, as well as ways to overcome the obstacles to homeschooling. Possible solutions are suggested for offering support to homeschoolers, including forming networks, increased support by supervising schools, the development of academic involvement in assisting new and experienced homeschoolers, and increased participation in solving short- and longer-term issues by the educational authorities.
\end{abstract}

Key words: lockdown, homeschooling, support, education, subsidiarity, opportunity, educational stability, restrictions

\section{Introduction}

With schools being generally seen as a significant cause of the coronavirus spread thus far in 2020-21, the standard forms of education in schools have been interrupted, and sometimes cancelled. This has been anything from an inconvenience to a complete lack of education, with some disruption being the norm. The loss of routine, structure, quality input, and access to resources has caused many practical problems. However, the longer-term effects on behaviour and approach to learning, qualifications, and even mental health and future job prospects may cause some to look for alternative educational systems or structures, as already seen, for example, in America, Ireland, and the UK. ${ }^{2}$

2 In America, significant numbers are turning to homeschooling as a safer and more stable option: cf. @ Arianna PROTHERO and Christina A. SAMUELS, 'Home Schooling Is Way Up With COVID-19. Will It Last?', Education Week (online), updated $11^{\text {th }}$ November 2020, available at: 
The only school-age children not disrupted in many countries are those in already established home education, commonly called homeschooling. This most subsidiarist form of education, which is not the commonly experienced contemporary 'homeschooling' in the time of virus restrictions, is mostly immune to problems in the school system. This suggests that the benefits of longer-term, planned homeschooling are worth exploring for families for whom it is a possibility. This paper $^{3}$ will consider the two key factors that lead families to begin homeschooling - reason and opportunity - particularly in light of the virus restrictions. Section 1 uses recent media sources to consider the effect of the disruption on teachers, students, and parents while, in comparison, section 2 describes homeschooling and briefly deals with some common objections to it. The third section shows the opportunity for homeschooling in the Czech Republic, describing the current state and the development of homeschooling as well as the legal requirements. Section 4 then looks at wider reasons for choosing to homeschool, which mainly concern the stability and wider educational possibilities that homeschooling offers regardless of wider societal issues. The fifth section then considers the problems and opportunities regarding homeschooling and how legislators, educational authorities, and academic experts can support new homeschoolers as well as help more experienced ones to develop their educational capabilities. Thus, by new and experienced homeschoolers being supported and enabled to develop their educational effectiveness, more children can thrive through home education which is more stable especially in times of disruption and is more suitable for some children for various reasons.

\section{Education in Restrictions Cause Restrictions in Education}

The Covid restrictions and their uncertainty have heavily affected the education of most children, ${ }^{4}$ who normally attend school institutions which are standard in industrialised economies. The three key groups - teachers, students, and parents - have been affected in specific and interlinked ways. It is useful to consider these in two linked ways: teacher-student and parent-student. These educational relationships have experienced almost entirely new situations, mostly negatively. However, from these challenges, solutions can be found and new ways developed.

The teaching and learning experience of professional teachers and school students has been highly affected. ${ }^{5}$ While some children have been enjoying at home a distance-learning style stable diet of educational input from their teacher(s), leading to some normality in content, ${ }^{6}$ if not location,

https://www.edweek.org/policy-politics/home-schooling-is-way-up-with-covid-19-will-it-last/2020/11, cited $1^{\text {st }}$ February 2021. The latest Census Bureau figures in the US show homeschooling doubling to 11\% of households: ๑ Mike SCHNEIDER, 'Homeschooling doubled from pandemic's start to last fall, AP (online), $24^{\text {th }}$ March 2021, available at: https://apnews.com/article/coronavirus-pandemic-census2020-6ca21124cca741b9e6ec1c8256e1c921, cited 11 $1^{\text {th }}$ August 2021. In Ireland, five times more families applied to become homeschoolers in August and September 2020 than in other years: cf. @ Carl O'BRIEN, 'Covid-19 fears spark record increase in homeschooling', Irish Times (online), 27 $7^{\text {th }}$ October 2020, available at: https://www.irishtimes.com/news/education/covid-19-fears-spark-record-increase-inhomeschooling-1.4391659, cited $1^{\text {st }}$ February 2021. Also, in the UK, the number of children leaving the school system to be homeschooled (i.e., not including those beginning education as homeschooled) in the 20-21 academic year rose by an average of $75 \%$, with more than triple the normal amount in some areas: cf. ๑ Alix Hattenstone and Eleanor Lawrie, 'Covid: Home-education numbers rise by $75 \%$ ', BBC News (online), $19^{\text {th }}$ July 2021, available at https://www.bbc.com/news/education-57255380, cited $21^{\text {st }}$ July 2021.

3 The author has teaching experience in a number of different forms of education for over 25 years, including 15 years as a primary school teacher (4-11-year-olds) in Britain and is now a homeschooler in the Czech Republic.

4 Cf. ( ) John CARPENTER, 'Homeschooling is a great way to fight the coronavirus', Classical Conversations (online), 27 ${ }^{\text {th }}$ August 2020, available at: https://members.classicalconversations.com/article/homeschooling-great-way-fight-coronavirus, cited $1^{\text {st }}$ February 2021.

5 Cf. ( ) Sara BUBB and Mari-Ana JONES, 'Learning from the COVID-19 home-schooling experience: Listening to pupils, parents/carers and teachers', (online), $14^{\text {th }}$ September 2020, available at: https://journals.sagepub.com/doi/full/10.1177/1365480220958797, cited $1^{\text {st }}$ February 2021.

6 Cf. ( $\odot$ Beatrice GOVE, 'Lockdown has been lonely and exhausting... Telling us our exams have been scrapped is the final straw, says A-level student Beatrice Gove', Daily Mail (online), $9^{\text {th }}$ January 2021, available at: https://www.dailymail.co.uk/debate/article-9129721/ Telling-exams-scrapped-final-straw-says-level-student-BEATRICE-GOVE.html, cited $1^{\text {st }}$ February 2021. 
many children receive less or even no input. ${ }^{7}$ This failure to provide a stable continuity of educational content has several possible causes, from teachers not providing a sufficient quality of content or accessibility, or for other domestic reasons.

Teachers supporting learners with some effectiveness have often tried to replicate the norm through electronic communications methods, presenting learners with online resources or custom-made ones using emailed instructions or videoconferencing for the class. While it is easier and more flexible to use recorded information (documents or videos), live video feeds are closer to the familiar educational paradigm of the teacher instructing students simultaneously and somewhat interactively.

Problems occur for both groups, however. For children learning by live video, it is necessary to be punctual online in an appropriate home location, with minimal interruptions. Sometimes attention must be given to a small image on a screen of the teacher amongst other images. It is difficult to pay constant attention to the teacher, with fewer educational stimuli (whiteboard, equipment, artefacts) available to support children's focus; instead, home can provide many distractions. Also, psychologically adapting to the teacher entering the home-environment may be difficult for children for different reasons. The current experiences will surely be rich areas for research for some educational specialists.

Meanwhile, it is problematic also for teachers. Some have less skills or confidence with unfamiliar IT equipment, new software, etc., and may not have a suitable home location for videos - live or recorded - to be produced. Teachers are trained to be presenters and facilitators of education in the (somewhat) controlled environment of the classroom, somewhat like a theatre stage, but it is now similar to a live television performance - it is recordable, parents may be watching nearby, and unfortunate errors may be shared or even uploaded publicly: famous videos showing family interruptions ${ }^{8}$ highlight potential problems so there is far more pressure to always 'get it right'. Additionally, planning and evaluating effectively in the completely new educational environment is necessary, which will be monitored by department heads, headteachers, and perhaps even inspectors. Then there is also the knowledge that returning to normal schooling will be a great challenge. And some teachers also must support their own children at home with their learning. While parents who are also teachers at least have understanding and experience to help them with their children, many do not. The child-parent relationship is not always conducive to education: some parents do not have suitable skills, experience, or opportunity. The structure and support provided at home for learners varies, for example, with personal and family time management, ${ }^{9}$ finding a quiet learning space, or providing sufficient computer access for each child. ${ }^{10}$ Parents' own level of education is also a factor, as is their attitude towards education, their relationship with the school, and particularly the teacher(s). For some children, it is impossible to find a location and a computer to access the teacher's communications, and of course some children were already disengaged from learning before the restrictions arrived.

Regarding all three groups, the schools provide a clear authority system built into the teaching

7 Cf. ( ) Basit MAHMOOD, 'Parents in U.K. Left with One Laptop for Four Children', Newsweek (online), 30 ${ }^{\text {th }}$ June 2020, available at: https://www.newsweek.com/coronavirus-schools-home-learning-u-k-education-1514390, cited 1 $1^{\text {st }}$ February 2021.

8 For example, (C) BBC News, 'Children interrupt BBC News interview - BBC News' (online), 10 ${ }^{\text {th }}$ March 2017, available at: https://www. youtube.com/watch? $\mathrm{v}=\mathrm{Mh} 4 \mathrm{f} 9 \mathrm{AYRCZY}$, cited $1^{\text {st }}$ February 2021.

9 For example, the parents of a first-year student chose to remove him from schooling until normality resumes: (C) Sarah PARCAK, 'We Love Our Kid. That's Why We Said No to Remote Learning', Time (online), available at: https://time.com/5828836/coronavirushomeschooling/, cited $1^{\text {st }}$ February 2021.

10 (C) Jane WAKEFIELD, 'Covid-19: The challenges of home-schooling', BBC News (online), available at: https://www.bbc.com/news/ technology-55573803, cited $1^{\text {st }}$ February 2021. 
and learning system. ${ }^{11}$ Authority is different at home - sometimes less clear or even non-existent - so some children may not be able to pay attention to learning in the home environment, leading to issues between the three groups. Also, as children deal psychologically with authority, respect, responsibility, and relationships with key adults differently in school than at home, the presence of the teacher in the home in a certain way now may cause issues in the child's social-psychological development.

Therefore, there are many new challenges to school education continuing without significant upheaval, which is becoming greater as restrictions lengthen. Teachers, learners, and parents are heavily affected in unforeseen ways. While many have done their best in the situation, the effects may be felt for a number of years. The only group who have not experienced these problems is homeschooled children.

\section{Homeschooling and Its General Advantages and Disadvantages}

Homeschoolers in general have been minimally affected by the restrictions. This is a minority, sometimes rare method of educating children which occurs in different cultures and different nations, with variations in how it is understood that include some negative perceptions. However, while homeschooling does not suit all children, it is generally found to be a positive and rich experience and has many potential benefits.

Sometimes called learning at home, home education, or unschooling (etc.), homeschooling regards children who are educated at home instead of at school. Without being Romantic with a rose-tinted view, it is useful to recall that homeschooling was the original form of education of most children and the experience of attending a school with a teacher and other pupils was uncommon in the more distant past; then, education beyond what was necessary for continuing the family trade or business was often classical liberal, designed to liberate the individual through education to become the best person possible. This changed due to the Enlightenment and Industrial Revolution. Both movements were enabled and reinforced in societies by having all children attend school in classes and receive specific education content to prepare them to be modern citizens and effective economic resources.

Homeschooling nowadays offers much freedom and many options. It enables the choice of either educational philosophy, thus for either outcome - to improve the person or his economic worth. There are also possibilities to develop certain specialisms, or to be more practical like continuing a farming tradition, etc. There are also options of more or less freedom in a child's learning, or even allowing the child to choose the learning, which is very different to following a curriculum and the teacher-parent instructing the child. The learning context can also be infused with the language, culture, and religious beliefs of the family, and perhaps the local area. Also, the time structure of the learning is variable regarding time of day, week, and even season. Homeschooling is more organic and less systematised, fitting better with the family as the child develops in a generally more caring and nurturing environment. Although different countries have more or less homeschooling regulations, which can limit some possible freedom in content, the structure is freer and some support offered for families can be beneficial.

Regarding learning, the advantages are many. The freedom to teach what and when is particularly helpful when children do not fit the school 'norms'. The non-average child is stronger or weaker in different skills and subjects, learns better with different styles, and sometimes needs more support

11 See John Taylor GATTO, Dumbing Us Down, Philadelphia (PA): New Society, 1992, pp. 4-12. 
or more freedom, all of which is possible with homeschooling. Schools are also very inefficient with time - homeschooled children can be taught far more quickly, freeing up time for projects, gardening, physical activities, specialisms, etc. Families with special characteristics, such as bilingualism, musical or artistic expertise, etc., can offer far more. Of course, the disadvantage is that parents must organise what to teach and how, provide resources and equipment, and ensure learning is at least sufficient.

The disadvantage, which can be considered as a positive challenge, is that schoolteachers and homeschoolers are both called to educate the young in a specific environment, but the latter are often not trained like the former. However, homeschoolers generally have strong personal incentives to develop their skills, becoming more proficient as they learn to educate their children better, which is not always so for teachers. It can happen that a homeschooler does not provide an education that is satisfactory, just as a teacher can fail. Whether support is received or the family must send the child to school, damage may have occurred to the child's development; improved education - at home or in school - usually leads to the child 'catching up'.

There are also some advantages socially for homeschooled children, especially when developing in small groups or individually, where most people feel more comfortable and social issues are solvable. It is not difficult in a school to identify some children who are uncomfortable in that environment. Some children prefer learning in a smaller group, avoiding many school problems like peer pressure to conform (fashionable clothes and phone, speaking like others, etc.) and sometimes aggression. Too often, teachers give less attention to good learners and well-behaved children, spending more time in dealing with children who prefer misbehaviour to learning. While some children can cope with different group environments, and some others learn to do so, there are those children who count the hours to the end of the school day, not because of schoolwork but social problems. For some, social issues are often magnified, not solved, by attending school. Of course, not every family is a healthy environment for a child but the generalisation that school is better socially for children is inaccurate. ${ }^{12}$ Learning in a more suitable environment, meeting the child's needs and preferences, often means that homeschooled children become more confident and well-rounded people.

Similarly, a common objection to homeschooling regarding socialisation says that homeschooled children do not mix with other children and lack social experience, which causes problems later in life. The assumption is that schooling is a satisfactory method of socialisation. However, homeschooled children develop in a more vertically structured social environment. The higher ratio of adults to children than in a school classroom is more representative of society and future workplaces. Regular access to people of other generations, including educationally such as extended family members ${ }^{13}$ means children can develop wider social skills with and respect for a greater range of people, for example, with regular visits to shops, libraries, museums, clubs, etc. On the other hand, schoolchildren have far more horizontally structured social encounters. For some, the discipline and regularity of schooling is suitable or even desirable: some children positively enjoy school. However, the disadvantages for many include being placed in a restrictive environment all day, with brief breaks around toilets and corridors, or outside in all conditions - weather and social. Being taught to behave and interact with the same group of people every day for a decade, with an occasional change in supervisor may have had utilitarian benefits in training a workforce

12 See, for example, John HOLT and Pat FARENGA, Teach Your Own, Cambridge (MA): Da Capo Press, 2003, pp. 20-23, 31-39.

13 Cf. ( $\odot$ Robin Marantz HENIG, 'Grandparents Could Ease the Burden of Homeschooling', The Atlantic (online), 10 ${ }^{\text {th }}$ September 2020, available at: https://www.theatlantic.com/family/archive/2020/09/use-grandparents-help-homeschooling/616225/, cited $1^{\text {st }}$ February 2021. 
for factories but it does little to develop the social experience and skills of children. The positive and hopefully enjoyable challenge for the homeschooling family is to develop the social skills, interactions, and integration of children within the family, in the local neighbourhood, and beyond. The homeschooled child has the potential to mix with a great variety of people of different ages, roles, abilities, and positions: the family must provide these opportunities.

It can happen that a homeschooled child is not taught sufficiently, or not given enough opportunities to learn social skills. This is where the homeschooling system can break down and fail. Equally, there are schools which do not provide a good learning and social environment, on a far larger scale. In both environments, good monitoring can identify problems. It is important that children's doctors, educational contacts, wider family, and the local community are able to intervene, as it is with problem schools and failing teachers. Therefore, where failure occurs in a homeschooling family, this is not the fault of homeschooling per se but of specific issues: a family that is failing in their duty of care and a social/legal system that cannot effectively identify problems and make appropriate interventions.

Therefore, homeschooling is a real option for some families - parents and children - who want an alternative to the societal norm of the school system. ${ }^{14}$ There are many advantages, more than those covered briefly here, for those who take up the often fulfilling and worthwhile challenge of homeschooling, particularly in the areas of learning and social development. Problems can often be overcome with dedication and perseverance. Where failure occurs, while the main responsibility is rightly with the parents as primary caregivers, there is also some responsibility on surrounding people and the state to intervene appropriately.

\section{Homeschooling in the Czech Republic}

The most subsidiarist method of educating children is homeschooling, which can take many forms - this is both an advantage and a disadvantage. It is far more flexible, more attuned to the life and experiences of the family, and offers some educational advantages to a child. It can also be difficult to organise, is heavily dependent on the family's experiences and situation, and it can be challenging to overcome certain restrictions. Some countries require that it is supervised and may offer support.

Regulations vary in different countries. While there is much freedom in Britain ${ }^{15}$ and different amounts in the American states, ${ }^{16}$ other nations require a range of limitations. ${ }^{17}$ However, homeschooling can be illegal, such as in Germany. In the Czech Republic, it is permitted in all compulsory years of education, from the final year of kindergarten to the end of basic school (5-15 years old), albeit there are requirements meaning it is 'heavily regulated': ${ }^{18}$ these include

14 Several stories of homeschooling being started due to the virus restrictions are presented in: @ Lucy Ballinger and Alex Jennings, 'Covid and home schooling: Children "flourishing" as numbers rise', BBC News (online), $25^{\text {th }}$ November 2020, available at: https://www.bbc. com/news/uk-wales-55063094, cited 21 $1^{\text {st }}$ July 2021.

15 (c) Nick MORRISON, 'Fears Children Going “Off-Grid” As Homeschooling Up By 700\%', Forbes (online), 6 ${ }^{\text {th }}$ March 2020, available at: https://www.forbes.com/sites/nickmorrison/2020/03/06/fears-children-going-off-grid-as-homeschooling-up-by-700/2 cited $1^{\text {st }}$ February 2021. There is no requirement in Britain to register homeschooled children (although there are current plans to change this) the estimated number was around 60,000 in 2018. Homeschoolers are only monitored if it is reported that no education is taking place.

16 Data available at: (c) Cato Institute, 'Freedom in the 50 States: Get the Data', available at: https://www.freedominthe50states.org/data, (online), cited $26^{\text {th }}$ January 2021, in spreadsheet in Personal tab. In 2016, the number of US homeschoolers was estimated variously at around 1.5 to over 2 million: in ( ) Brian D. Ray, Homeschooling Growing: Multiple Data Points Show Increase 2012 to 2016 and Later, NHERI (online), available at: https://www.nheri.org/homeschool-population-size-growing/, cited $26^{\text {th }}$ January 2021.

17 The general range is shown at Wikipedia, but details may be inaccurate: @ Wikipedia, 'Homeschooling international status and statistics', (online), available at: https://en.wikipedia.org/wiki/Homeschooling_international_status_and_statistics, cited $27^{\text {th }}$ January 2021.

18 As described in ibid., 'Czech Republic' section. 
the educator's (parent or hired teacher) level of education, ${ }^{19}$ being supervised by a school, being assessed twice yearly, and to have the agreement of an educational psychologist. ${ }^{20}$ In 2019-20, there were approximately 3,900 homeschooled children in the Czech Republic; Březová school supervises 970 of these. ${ }^{21}$ The Czech Republic has homeschooling history: it continued for some even after compulsory schooling began in 1774 and regulation of their standards of learning began in $1905 .{ }^{22}$ Homeschooling was outlawed in 1938 by the German authorities, ${ }^{23}$ but it is unclear whether this applied also in the Czech lands. It was banned by the communist education law of $1948 .^{24}$

Homeschooling in the Czech Republic, called Individual Education (Individuální vzdělávání), for children aged 6-11 (lower basic school) has been legal since 2005, after a very highly regulated experimental 7-year period. ${ }^{25}$ A similar experiment started in $2007^{26}$ for children in the remaining compulsory years (12-15 year olds in upper basic school) which resulted in full legalisation in 2016. ${ }^{27}$ From 360 children in 2006, this nearly doubled by 2012. Since 2012, the trend increase has been nearly 1.5 times yearly, ${ }^{28}$ to its present amount. Therefore, with almost one million children at compulsory school age, ${ }^{29}$ homeschooling occurs at a frequency of $0.4 \%$, or 4 in every thousand. As this develops, leading to more people spreading positivity about the option, homeschooling will probably continue to grow in popularity, possibly even more quickly due to current social restrictions. This means that regulation and support of homeschoolers may need to be reviewed and developed by educational authorities.

Březová school supervises and assesses around one quarter of homeschooled children in the country even though it is near the Slovakian border. With just over one hundred attending the school 'normally', most of its registered students are homeschoolers whom the school assesses in several locations across the country twice yearly. In 2016, the government recommended homeschoolers to seek support from their schools: 'Individually educated pupils can, on the basis of an agreement with the school, participate in the education of their year group through e-learning, games or interactive educational programs, which is also beneficial for pupils with learning disabilities.' ${ }^{30}$ Březová school offers a range of lessons and other resources, which are optional

19 For lower basic school (6-11-year-olds), a graduate of middle school (around 18 years old); for higher basic school 12-15-year-olds), a university degree.

20 C Education Act 561/2004 Coll. $\$ 41$, (online), available at https://www.msmt.cz/uploads/skolsky_zakon.pdf, cited 1 ${ }^{\text {st }}$ February $2021, \$ 41$.

21 Data in January 2021: cf. @ ( Školy Březová, 'O nas', (online), available at http://www.skolybrezova.eu/o-nas/o-nas, cited $26^{\text {th }}$ January 2021.

22 (C) Jiří NĚMEČEK, Home and Community Schooling in the Czech Republic, United Kingdom and the USA, Diploma Thesis, 2017, Masaryk University, Brno, (online), available at: https://is.muni.cz/th/h1s9l/Home_and_Community_Schooling_in_the_Czech_Republic_ United_Kingdom_and_the_USA.pdf, cited $26^{\text {th }}$ January 2021, pp. 40-41.

23 Ibid., p. 38.

24 Ibid., p. 41.

25 C) Yvona KOSTELECKÁ, 'Home education in the post-communist countries: Case study of the Czech Republic' in International Electronic Journal of Elementary Education Vol. 3, Issue 1(online), October 2010, available at https://web.archive.org/web/20111021050558/http:// www.iejee.com/3_1_2010/29_44.pdf, cited $1^{\text {st }}$ February 2021, pp. 32-34.

26 (C) Ministry of Education, Youth and Sports, 'Proclamation of experimental period', (online), 23 ${ }^{\text {rd }}$ May 2007, available at: http://www. msmt.cz/file/9571_1_1/, cited 30 January 2021.

27 C Czech School Inspectorate, Thematic Report, 2016, (online), available at http://www.atre.cz/aktuality/stahni/id/581, cited $1^{\text {st }}$ February 2021, p. 3.

28 Approximate numbers from the graphed data at: @ Ludvík ZIMČÍK, Udělejme si školu doma aneb: Jak na domácí vzdělávání?, blog entry on $10^{\text {th }}$ October 2017 (online), available at: http://www.skolybrezova.eu/o-nas/rediteluv-blog/491-udelejme-si-skolu-doma-anebjak-na-domaci-vzdelavani, cited, $20^{\text {th }}$ January 2021; also (C) Martin Mana, 'Jak se mění počty žáků na základních školách', (online), $30^{\text {th }}$ September 2020, available at: https://www.statistikaamy.cz/2020/09/30/jak-se-meni-pocty-zaku-na-zakladnich-skolach, cited $20^{\text {th }}$ January 2021.

29 Martin Mana, 'Jak se mění....

30 () Ministry of Education, Youth and Sports, 'Information and Recommendation of the Ministry of Education, Youth and Sports regarding Individual Education Students in Basic School', (online), $11^{\text {th }}$ October 2016, available at https://www.msmt.cz/file/46873_1_1/, cited $1^{\text {st }}$ February 2021, p. 9. 
for home use. These are particularly useful for parents for a number of reasons. It can be hoped that further cooperation between homeschoolers and schools can develop, perhaps assisted by educational authorities, leading to new forms of education.

In almost 40 years of education, Březová School's headteacher, Ludvík Zimčík, has encountered five general types of homeschoolers in the country, reflecting previously mentioned themes: children who have specialist training in school time, for example, athletes; those who have suffered from bullying; those with medical reasons or learning needs; those whose parents have clear values they want to pass on (such as religious or a nature-focused); and those dissatisfied with mainstream schooling and seek a different education style. ${ }^{31} \mathrm{He}$ also confirms that he has never encountered extremists but has rather found that homeschooling parents have significant reasons for choosing this form of education and care for their children. ${ }^{32}$

The Czech trend for homeschooling is increasing. Legislation has increasingly enabled home education in recent decades, while requiring certain standards to be maintained. The question is whether it will increase further due to the current restrictions, like Christopher Lubienski foresees in America:

\begin{abstract}
'Because of the pandemic crisis, some people ... may have lost their job anyways, so educating at home becomes much more possible, said Lubienski.

He also thinks home schooling will become more mainstream and socially acceptable, now that so many people are getting experience with schooling their own children from home-whether it's through traditional home schooling or overseeing their children's remote schooling. ${ }^{33}$
\end{abstract}

Thus, homeschooling is regulated in the Czech Republic, where numbers are small but growing significantly. Learning at home occurs for a number of possible reasons which are expanded on below. Then we will consider the obstacles needing to be overcome, particularly in the Czech context.

\title{
4. Reasons for Homeschooling, Particularly in Light of Restrictions
}

The virus restrictions have been highly disruptive to school children at all levels, ages, and abilities. However, the learning of homeschooled children has been for the most part unaffected because it is based around the home, which is more stable and robust than elsewhere during societal problems. Families homeschool for a number of reasons: some are now more clear due to enforced home education, and these further reasons may lead to parents and children choosing permanent homeschooling after the restrictions are lifted, as has happened in America, for example. ${ }^{34}$ This somewhat extreme situation was unforeseen, thus insufficiently planned for by any nation. Parents will be concerned about the length of current virus restrictions as well as the possibility of future restrictions, which potentially could occur for a number of reasons. Currently, the hope of many is in vaccines and herd-immunity, but there is no guarantee of a return to normal,

31 Ludvík ZIMČÍK, 'Udělejme si školu...'

32 Ibid.

33 @ A Arianna PROTHERO and Christina A. SAMUELS, 'Home Schooling Is...'

34 A number of such situations are described in ( ) David CRARY, 'Sparked by pandemic fallout, homeschooling surges across US', AP (online), $26^{\text {th }}$ July 2021 , available at: https://apnews.com/article/health-religion-coronavirus-pandemic-race-and-ethnicity-5385d17b9f 91591f4baae71bafb71f0c, cited 11 ${ }^{\text {th }}$ August 2021. 
particularly due to new virus strains. The uncertainty is exacerbated by the media, who can exaggerate stories to attract sales and online clicks, creating both hope and despair and thus instability. For some concerned parents, homeschooling may be a solution to some of the problems.

Other factors, whether specific in the Czech Republic or also in other countries, can potentially cause disruption and problems in children's education, from the widespread to the personal, from temporary to ongoing: inclement weather; transport issues in public infrastructure or private transport; styles of education; the curriculum followed by schools; issues with local schools; religious beliefs; lifestyle choices; peer pressure and bullying; special needs and high performing children; and specialisms such as language. Some parents may respond to such reasons by seeking to secure more stability in their children's education.

International or regional issues might, for example, lead to transport or funding problems, including conflicts regarding oil producing nations, global financial instability, future weather extremes of which some scientists warn, electric vehicle technology being too expensive, etc. The list of potential problems is long and much of it signals uncertainty and instability. The very fact that a virus mutation in East Asia can cause such a global effect points to benefits in increased subsidiarity, of keeping things more local: in the educational context, this means learning within one's own household.

Also, people are becoming more aware of different styles of education. The standard classroom style was effective for the needs of an industrialised society and it improved in recent decades in many ways. However, it is still based on the one-size-fits-all classroom system, which is very inefficient with time and the needs of individuals or small groups. An organised homeschooler can provide a whole day's classroom education in less than a whole morning, while offering a personal approach and content which fits the child's interest and needs, leading to extra project time, gardening, arts and crafts, or an outing (albeit restricted currently). At home, frustration or disengagement of the child from learning can be greatly reduced and behaviour is not generally an issue as learning is more integrated and natural. Within the virus restrictions, recreation in the garden or park is surely better than a masked, restricted time in a segregated playground or corridor. This means the more organic structure of homeschooling is far more suited to the intellectual and personal development of the individual child.

Curriculum content issues can be a problem for some parents. In school, some children are exposed to themes that parents prefer their children to be introduced to later or in a different way, such as violence, sexual matters, political content and leanings, societal themes, etc. Examples can be early reading books with postmodern gender stereotype ${ }^{35}$ and the common theme of children constantly outwitting out-of-touch adults. Also, curriculum style can be unhelpful: some children benefit from the spiral method where, for example, addition is practised for a week in maths, then the next week the focus is shape, and so on; instead, some children learn more effectively a whole discipline for a month or longer. Also, if a child is not ready for a particular skill, it is simple to defer it at home, which a school cannot do. Homeschooling allows flexibility with structure, style, and content, being adaptable to the family's and learner's preferences. Parents may currently perceive problems more in what their children are learning and seek to take control of it through homeschooling.

Local schools can be a factor. Relationships between parents and schools and staff are varied. Causes can be the personalities involved and the style of schooling on offer. Some staff welcome

35 For example, the Oxford Reading Tree series for new and developing readers: Dad is portrayed often as clumsy and foolish, while his daughter sometimes clearly looks down on him. 
parents, others erect a wall; some parents want to be involved cooperatively, some don't want to be cooperative, and some don't want to be involved. Also, school policies might cause problems - a growing issue in some countries like America is gender-neutral toilets, where all people use the same facilities, or choose whichever segregated toilets they prefer. This is to make a very small minority feel more comfortable, while ignoring the majority's comfort, and even safety. In these restricted times, parents may have problems with education authorities, school management, or even daily with teaching staff, including those demanding their routines are followed even if they disrupt home life. A lack of quality resources or teaching can cause parents to fill the gaps; these issues point towards permanent homeschooling being a possible solution.

An area that can be a problem is religion in education or the lack of it in today's mostly secular humanist societies. In some countries, religious schools are common or somewhat available and can be effective in developing children in their religious understanding and experience but many are not, paying only lip service to the school's advertised religion. Some countries have no faithbased schools or only offer a secular education during curriculum time, like the Czech Republic. Sometimes a local school offers a religious content and/or context that differs from a family's beliefs, sometimes within the same religion or even denomination. And sometimes parents must deal with their children being exposed to themes or teachings in school which are against their beliefs, possibly leading to a dichotomy of trust and authority for the child. The restrictions have increasingly enabled families to educate their children in a faith context and with content more in accord with the family's faith. For some, the thought of their children returning to a problematic, or even toxic, educational environment can lead to permanent homeschooling.

Homeschooling enables an educational input that is rich in faith and the teachings of the family's beliefs. Secular schooling somewhat causes children to intellectually develop separate from their faith, leading to some level of disagreement between worldly learning and a faith life. Instead, homeschooled children can be taught the general curriculum in accordance with home beliefs, thus developing intellectually in their faith. A contemporary example is that most major Covid vaccines are sourced in some way from tissue from aborted foetuses, ${ }^{36}$ a serious ethical issue for many religious. This can be a rich area of teaching in ethics for older children, where they can, for example, learn that the Catholic Church is against this. ${ }^{37}$ However, the Church points out that while vaccinations 'must be voluntary', ${ }^{38}$ it ethically recommends that the faithful receive the unethical vaccines if there is no ethical one available or 'do their utmost to avoid, by other prophylactic means and appropriate behavior,' ${ }^{39}$ and should make protestations about the unethical source. ${ }^{40}$

Similar issues occur with lifestyle and family tradition preferences. For example, a self-sufficient family will be against using transport to go to school. Technology-keen parents may prefer their child learning to program rather than (years too late) how to use a search engine. Beliefs and

36 C Children of God for Life, 'Covid-19 Vaccines and Treatments in Development - Updated Dec 28, 2020', (online), $28^{\text {th }}$ December 2020, available at: https://cogforlife.org/wp-content/uploads/CovidCompareMoralImmoral.pdf, cited 30 th January 2021.

37 C Pontifical Academy for Life, 'Moral Reflections on Vaccines Prepared from Cells Derived from Aborted Human Foetuses', letter dated $9^{\text {th }}$ June 2005 (online), available at: https://cogforlife.org/wp-content/uploads/2012/04/vaticanresponse1.pdf, cited 2021, summarised on pp. 7-8.

38 (C) Luis LADRIA and Giacomo MORANDI, 'Note on the morality of using some anti-Covid-19 vaccines', Congregation for the Doctrine of the Faith (online), $21^{\text {st }}$ December 2020, available at: http://www.vatican.va/roman_curia/congregations/cfaith/documents/rc_con_ cfaith_doc_20201221_nota-vaccini-anticovid_en.html, cited $30^{\text {th }}$ January 2021, 5.

39 That is, presumably, face masks and social distancing. Ibid.

40 Cf. ( ) Stacy Trasancos, 'How to Object to an Abortion-Tainted COVID-19 Vaccine', National Catholic Register (online), $21^{\text {st }}$ December 2020, available at: https://www.ncregister.com/commentaries/how-to-object-to-an-abortion-tainted-covid-19-vaccine, cited $30^{\text {th }}$ January 2021; also cf. @ Pontifical Academy for Life, 'Moral Reflections..., p. 7. 
preferences of families are highly varied and mainstream schooling cannot educate all children effectively in an increasingly fragmenting world where people's interests and abilities are less formulaic. Regarding educational philosophy, some parents may prefer the traditional goal of developing the individual to his fullest rather than to be an effective resource for society and more worldly success. The former is achieved more readily through a classical liberal style, or also with some modern alternatives. The latter is served by the industrial system of schooling groups of children and socialising them in large groups of their peers to produce future workers suited to a workforce, but this is arguably more suited to the past. The restriction experiences of some may lead to a reconsidering of the aims of a child's education.

In the system of schools, peer-pressure and bullying are enabled. Some children feel at least uncomfortable in large groups of peers. They suffer either for personal reasons - a lack of confidence, social skills, or suitable potential friends - or group issues such as being branded unfashionable, unlikable, different, etc. While some children develop socially by being thrown into the social mix, for others it is uncomfortable at best and tortuous at worst. A group of children tends to follow the strongest personalities, often leading to the lowest common denominator over time. Outsiders must learn to comply or are unwelcome. Therefore, for some children, schooling is socially problematic, and having happily stayed at home and found it more comfortable to learn there, the idea of returning to school will be a problem. This could conceivably be the deciding reason for some parents to opt for permanent homeschooling.

For some homeschoolers, their child does not fit the learning categories that suit generalised teaching. Although teachers differentiate lessons, for some children their needs will rarely be catered for. Children with slower learning development can have a more suitable teaching at home without feeling different or a failure. Also, those who are several years ahead in learning are not encouraged to dull their desire to learn so they can fit with the crowd or suffer boredom which can lead to poor behaviour. In some schools, the academic child must choose between success or acceptance; alternatively, amongst successful peers, the unsuccessful learner struggles for acceptance or becomes the class clown. For these children and their parents, the virus restrictions may have opened up a whole new experience: being met where they are and supported and enabled better.

Finally, there are homeschooled children who benefit from a specific factor: a musical environment as the parents are musicians; a practical upbringing that is developed along with academic learning; a bilingual child learning in both languages; or a child whose parents can teach him more effectively than variously skilled professionals in front of thirty children who by the time they know the child effectively enough, the conveyor belt moves on and a new batch appear in September. According to the teachings of the Catholic Church, the parents are the primary and principal educators. ${ }^{41}$ Regardless of capabilities, they know the child, care for the child, and love the child best, holding his best interests at heart. While somewhat ideal, this is an ideal that is strengthened by homeschooling when done for the right reasons, which may have become clear to some parents in the current time.

Homeschooling can be done, of course, for the wrong reasons, but this is not the norm. There is a certain cliché that homeschoolers are not normal, are social misfits, or even extremists. While

41 (c) Second Vatican Council, Gravissimum Educationis, (online), $28^{\text {th }}$ October 1965, available at http://www.vatican.va/archive/hist councils/ii_vatican_council/documents/vat-ii_decl_19651028_gravissimum-educationis_en.html, cited 30 ${ }^{\text {th }}$ January 2021, 3. See also (C) Pontifical Council of Justice and Peace, Compendium of the Social Doctrine of the Church, (online), available at: http://www.vatican. $\mathrm{va} /$ roman_curia/pontifical_councils/justpeace/documents/rc_pc_justpeace_doc_20060526_compendio-dott-soc_en.html, cited 30 $0^{\text {th }}$ January 2021, 238-243. 
the last could be true for a very small minority, we always hear of the extremes, not the common vast majority who do not inspire gossip. As abovementioned, Březová School's headteacher has never encountered a family where extremism was the reason for homeschooling.

The default choice for parents must be the normal school system as it is the safety net in terms of requirements. The decision to homeschool cannot be lightly taken. However, there are many reasons for home educating children where this is possible. And where children can clearly benefit from homeschooling, it is the parents' responsibility to genuinely consider if it is possible to facilitate this. Currently, children and parents have a taste of the homeschooling lifestyle, albeit usually without the full responsibility of structuring, resourcing, and implementing education at home. This means that now some parents ${ }^{42}$ have a clear reason for homeschooling, like a catalyst, but they might not have the ability or opportunity to choose this method of education.

\section{Taking up the Challenge, with Support}

While there are many reasons to start homeschooling, interested parents may feel the opportunity is not there as different pressures in life can thwart it. While some sacrifices need to be made, there is some support available, however, much more could be done to help parents beginning to educate their children at home. In the Czech Republic, solutions can sometimes be found in the home and family, and appropriate support could come through the involvement of legislators, educational authorities, and academic experts.

The first barrier to homeschooling is usually time. In postmodern society, both parents in the traditional family structure have been strongly encouraged to work, often full-time. Fitting well with full-time schooling, this economic-social paradigm has been the standard model in the Czech Republic since the post-war period, devaluing the traditional image of a stay-at-home parent. For single parents, the challenge to homeschool is especially great but it is still possible in some cases. ${ }^{43}$ While flexibility has developed for decades in some cultures - part-time work, self-employment, job-shares, flexi-time, and home-office - the Czech Republic is still strongly inflexible, with full-time attendance at the workplace the norm.

However, changes are beginning to occur: job-sharing is permitted by a recent employment law development. ${ }^{44}$ Also, the virus restrictions hopefully will have shown that a more flexible approach is possible, with flexibility solutions to be found in more part-time contracts, non-standard hours, and staff working effectively from home. Also, a review of self-employment laws and taxation levels could encourage more self-employment, ${ }^{45}$ enabling opportunities for reorganising a family's home-life to include homeschooling.

Time allocated for homeschooling does not need to be a large portion of the day. It can be divided into smaller timeslots at suitable times. The key factor is clear organisation and regular reviewing of effective use of time. While schools are inefficient with overall time management, a family can choose when to learn, work, relax, play, be together, and be individuals. With good will and effort,

42 In America, some parents are now convinced it is time to start homeschooling: ( ) Emma Green, 'The Pandemic Has Parents Fleeing From Schools-Maybe Forever', The Atlantic (online), 13 ${ }^{\text {th }}$ September 2020, available at: https://www.theatlantic.com/politics/ archive/2020/09/homschooling-boom-pandemic/616303/, cited 30 $0^{\text {th }}$ January 2021.

43 See Mary Kay CLARK, Catholic Home Schooling, Rockford (IL): Tan Books, 1993, pp. 258-265.

44 ( ) Act 285/2020 Coll., (online), 10 $0^{\text {th }}$ June 2020, available at: https://www.epravo.cz/_dataPublic/sbirky/2020/sb0108-2020.pdf, cited $1^{\text {st }}$ February 2021, \$317a.

45 The current Czech tax system regarding self-employment presumes it is a second income and that the person is already in employment. After registering as self-employed with no other job, the person must pay significant health and social taxes, even if there is little or no income from the self-employment. Therefore, it can be a real financial risk to enter into self-employment without a guaranteed income. 
a family can discover what works best. Also, learning does not need to follow the standard model of teacher input for 20-30 minutes then a supervised child activity of a similar time. Efficient teaching input, suited to the child's educational needs and preferences, should often take only a few minutes. Activities can be checked on regularly, perhaps every 10 minutes. Breaks and many activities require almost no supervision. Thus, an hour's learning can require 10 minutes of adult time, giving much of the hour to the home-working adult's tasks. This is not guaranteed in every situation but can occur often and with practice can improve. What is important is that work and learning are both organised so that neither suffers regularly.

A second major stumbling block can be what to teach. This can be divided into structure and resources. Within structure is also content, particularly in the Czech system where children are assessed, so knowledge of the curriculum is important; however, it is a useful tool as a measure and roadmap for learning. The supervising school ideally should offer some assistance when requested, but it is the parent's responsibility to develop understanding of how to structure the learning. Basically following the list of requirements is sufficient, but should be developed over time. Support should also be sought and provided regarding children below or above standard ability.

Regarding resources, some languages have a large choice of books, software, and other resources, especially online, without cost. For example, a full curriculum can be taught in English without any payment, requiring only time and patience to locate suitable resources online. In Czech, resources are much more limited, but this is improving yearly. Well-selected words in an online search can supply very useful and valuable results. Khan Academy and Duolingo both include Czech content; the former offers structured content in many subjects and the latter can be a gateway to using other languages for learning resources. Bookshops also offer many resource books, especially in September, to support learning, and resources can also be made at home. But most important is to discover what works for the child and how he learns effectively.

As mentioned before, the Czech regulation requiring school supervision and assessments can lead to the school providing some support. This can develop distance learning, like at Březová School, which offers teaching content by video as well as give advice. Assessment is through uploaded learning output - writing, pictures, projects, videos, etc. - in a portfolio as well as face-to-face at several locations across the country each semester in normal times. However, some schools agreeing to supervise homeschoolers are relatively inexperienced with this and are unsupported themselves regarding the needs and delivery of education at home; this can lead to anything from overly supervised demands to follow particular books - so homeschooling is merely schooling done at home - to superficial supervision which could potentially lead to children receiving inadequate education. ${ }^{46}$ Some homeschoolers are happy with more freedom, but this is not so helpful to many who are starting out. Ideally, each region would have at least one school specialising in supervising homeschoolers, like Březová; these could be overseen by an education specialist who understands the reasons for and issues of homeschooling, to avoid the role simply being regarded as a level of control by the state.

Networks can be a very effective way of developing homeschooling. New homeschoolers can be recommended a suitable supervising school and offered advice with time management and locating and sharing resources. Experienced home educators can share ideas and methods, inspiring others to develop confidence and effectiveness. Also, geographically-formed clusters can organise group activities and outings, and share information, such as about music and sports specialists

46 This concern has been shared with the author by several experienced homeschoolers in conversations. 
or native speakers of the languages being learned. They can also share in the teaching of each other's children, taking advantage of their specialisms, enable group activities and projects, and take turns in supervising the group to allow others time for work, etc. Finally, being able to talk with someone who understands one's situation is of great importance. Of course, as numbers of homeschoolers increase, more networks can develop by improving their diversity, from specialisms to personalities.

On another level, especially as the virus restrictions may lead to increased interest in homeschooling in the Czech Republic, the academic involvement of educational specialists could be developed to offer support to the growing number of homeschoolers. Research and development of ideas is important: some countries have large numbers of homeschoolers and systems of support, and these can be learned from but it must be adapted to the Czech homeschooling environment. Practical support for prospective and existing homeschoolers can be provided by academic specialists regarding organisation, introductory content, and the development of (semi-) experienced homeschoolers; key areas include time-management, increasing resources, or increasing effectiveness with the curriculum and resources. While schoolteachers are trained and then access ongoing training, homeschoolers are not: although some may not be interested in this, an offering of optional support would help others, and encourage those considering homeschooling. Also, training and support for supervising schools and staff could be beneficial, perhaps leading to specific supervision and support standards being developed. The idea of a homeschooling hub could help develop local networks, support more specialist schools, and develop useful resources and curriculum understanding in parents. Through this, models of teaching could be shared, from different styles to daily and weekly organisation. Carried out within the academic environment, this would enable developments in the quality of homeschooling to be spread, while being sympathetic to the fact that different homeschoolers prefer varying levels of support, or none. In general terms, academia could become very supportive to homeschooling, both in developing theory as well as practice.

One final but important issue that may be problematic in the current time in the Czech Republic is that if some families opt to homeschool after virus restrictions, management of this situation regarding the legal requirements of finding a supervising school and having a positive educational psychologist report would be very helpful for all. By managing this potential problem, the educational authorities could minimise or even avoid the possible situation of schools and teachers having to deal with parents and children who have already chosen not to be there, leading possibly to disruption and discontent just at the time when schools are trying to restabilise and return to normal. Possible solutions could be a database of schools who will supervise and a time extension for meeting a psychologist if an appointment has already been organised.

Therefore, with more support from the state in the form of more flexible working conditions, tax levels, self-employment regulations, and even increased organisation of supervision, homeschooling can be enabled as a serious possibility for more families where some children can benefit from a more suitable education. With more organisation and by developing networks, homeschoolers can support one another, sharing ideas and resources as well as time. And academic support for new and experienced homeschoolers can be offered, as well as for supervising schools. With increased opportunities, more families can be enabled to homeschool and the quality of homeschooling can be developed to improve learning as well as increase happiness and purpose in family life. 


\section{Conclusion}

During the virus restrictions in society, schoolchildren have had problems with learning at home, as have parents and teachers as they try to provide some level of ongoing education. On the other hand, homeschooling, which has been practically unaffected, is a very small but growing option taken by parents who choose to educate their children at home; in the Czech Republic, this is regulated, requiring a school to supervise and assess such children. For some, this time under restrictions has been an opportunity to explore education at home, albeit with more intrusion into the home by schools than with normal homeschooling. The children who have benefited from learning at home and the parents who prefer this, for various possible reasons, and who consider themselves capable of providing effective home education may be considering their options. Many obstacles can block the opportunity to homeschool and prevent homeschooling from taking place but recent employment law changes will ease some problems. With further changes to legislation and employers allowing more flexibility once restrictions are lifted, more parents can have the opportunity to homeschool their children. However, to find solutions to some problems, challenges need to be overcome and sometimes sacrifices need to be made. Some solutions can be the development of resources, support for new and existing homeschooling families, and networks developing, leading to more opportunities to improve the homeschool experience and its effectiveness.

Academia can also play an important role: from supporting and advising new homeschoolers to giving experienced practitioners a platform for sharing ideas; from supporting networks and creating educational hubs to developing ideas regarding how educational authorities can more effectively support and oversee homeschooling; and to develop the general level of homeschooling by homeschoolers as well as help supervisory schools become more effective and efficient in not only assessing children's development but also in offering ways of supporting this.

Through all working together - homeschoolers, supervising schools, educational authorities, and academic experts - homeschooling can be delivered, supported, and overseen with higher standards while respecting a healthy freedom within this form of education, which may be a serious consideration for some families coming out of the current virus restrictions.

\section{Contact}

\section{Stuart Nicolson, MA}

University of South Bohemia in České Budějovice

Faculty of Theology

Department of Philosophy and Religious Studies

Kněžská 8, 37001 České Budějovice

snicolson@tf.jcu.cz 